\title{
Emerging Market Mutual Fund Performance: Evidence for Poland.
}

\author{
Jędrzej Białkowski ${ }^{*}$ \\ Department of Economics and Finance, University of Canterbury, Private Bag 4800, \\ Christchurch, New Zealand.
}

Roger Otten

Maastricht University and Philips Pension Fund, PO BOX 616, 6200 MD Maastricht, The Netherlands

\begin{abstract}
This paper provides evidence on the performance of mutual funds in a prominent emerging market; Poland. Studying an emerging market provides an excellent opportunity to test whether the consensus on the inability of mutual funds in developed and highly efficient markets to beat the market, also holds in less efficient markets. While the weaknesses of legal institutions and underdeveloped capital markets in emerging countries could negatively contribute to performance, a certain level of market inefficiency might also enable fund managers to successfully apply security selection and therefore beat the market. This paper presents an overview of the Polish mutual fund industry and investigates mutual fund performance using a survivorship bias controlled sample of 140 funds. The latter is done using the Carhart (1997) 4-factor asset-pricing model. In addition, we investigate whether Polish fund managers exhibit "hot hands", persistence in performance. Finally the influence of fund characteristics on risk-adjusted performance is considered. Our overall results suggest that Polish mutual funds on average are not able to add value, as indicated by their negative net alphas. Interestingly, domestic funds outperform internationally investing funds, which points at informational advantages of local over foreign investors. Finally, we detect strong persistence in mean returns up to 1 year. It is striking that "winning" funds are able to significantly beat the market, based on their significantly positive alpha's. These results deviate from studies on developed markets that conclude that even past winners are not able to significantly beat the market.
\end{abstract}

JEL classification: G12, G20, G23,

Keywords: Mutual funds, Performance evaluation, Polish mutual fund industry, Emerging market mutual funds, Emerging stock markets in Central Europe.

\footnotetext{
* Corresponding author: Tel. +64 3 3643316; fax: +64 33642635.

E-mail address: jedrzej.bialkowski@canterbury.ac.nz (Jedrzej Bialkowski).
} 


\section{Introduction}

Studying mutual funds has served as an excellent laboratory for numerous researchers interested in testing for market efficiency. Based on over 4 decades of mutual fund performance studies there now exists a strong consensus on the inability of mutual funds to beat the market after all relevant fees are deducted. More specifically, the alpha's on the estimated factor models are significantly negative, by about the amount equal to the fees that are charged. The vast majority of these studies however focused on the US mutual fund industry which in terms of assets under management and holding of the domestic equity market is far ahead of the rest of the world. ${ }^{1}$ More recently several studies turned to European mutual funds as data coverage on non-US markets improved. However, most European studies focus on individual countries, which makes it difficult to draw comprehensive conclusions across countries. ${ }^{2}$ A notable exception to this is offered by Otten \& Bams (2002). By studying a survivorship bias free sample of 506 mutual funds from France, Germany, Italy, United Kingdom and The Netherlands they find that the average European mutual fund produces an alpha that is insignificantly different from zero. Adding back management fees, led to 4 out of 5 countries exhibiting significant outperformance at an aggregate level. The authors argue that the smaller market importance of European mutual funds might put them in a better position to follow or even beat the market. This in sharp contrast to US funds which represent over $30 \%$ of stock market capitalisation, while European funds only represent about $10 \%$ of their local stock market capitalisation.

Evidence on emerging market mutual funds is scarce. Based on for instance Ferraira et al. (2006) and Khorana et al. (2005) there is a positive relation between risk-adjusted

\footnotetext{
${ }^{1}$ See for instance Jensen (1969), Malkiel (1995), Gruber (1996), Carhart (1997) and French (2008).

${ }^{2}$ For instance Dermine and Röller (1992) on French mutual funds, Ward and Saunders (1976), Shukla and Imwegen (1995) and Blake and Timmerman (1998) on UK funds, Wittrock and Steiner (1995) on German funds, Ter Horst, Nijman and De Roon (1998) on Dutch funds, Fernandez. (2008) on Spanish funds, Sorros (2001), Rompotis (2007) on Greek funds, and Dahlquist, Engström and Söderlind (2000) on Swedish funds.
} 
performance and variables like the strength of legal institutions and the development of the capital market. Following those arguments it is expected that emerging market mutual funds underperform. On the other hand, several studies of emerging market mutual funds based in mature markets document an outperformance. For instance, Borensztein \& Gelos (2000) have shown that managers of emerging market mutual funds are characterised by better market timing. On average, they were able to rebalance their portfolios at least one month before a crisis. A more recent study by Huij \& Post (2009) finds that US mutual funds investing in emerging markets are able to generate returns that are sufficiently large to cover their expenses. Also, the authors document a strong persistence in performance of past winners over past losers. They conclude by stating that emerging market funds generally display better performance than US funds. The two above mentioned studies are based on emerging market funds, based in mature markets (such as the US). Based on informational advantages one could suspect that local (domestic) investors would outsmart foreign investors, especially in emerging markets. This is well documented by for instance Brennan \& Cao (1997), Coval \& Moskowitz (1999) and Hau (2001). Otten \& Bams (2007) examine local versus foreign mutual fund performance in a developed market, the United States, and find no difference. Therefore, our study will focus on mutual funds, operating and investing in an emerging market, in contrast to previous studies that scrutinize emerging market funds from mature markets investing in emerging markets. We choose to study the Polish fund market for three reasons. First, in the group of Central European countries that became members of the European Union (EU), Poland was characterised as the most developed mutual fund market. Secondly, the Polish fund market provides an opportunity to study a fast growing market. During the 8 year period of our analysis the number of funds grew by $23 \%$ per year and the total value of assets under management grew tenfold. Thirdly, in contrast to studies on Polish pensions funds by Voronkowa and Bohl (2005) and Stanko (2003) studies on the Polish 
mutual funds market are scant. To our knowledge the only published study on the topic is by Swinkels \& Rzezniczak (2009). Based on a sample of 38 surviving funds from January 2000 - April 2007 they conclude that Polish funds produce 1-factor CAPM alpha's that are insignificantly different from zero. We extend the above mentioned analysis of Polish funds by Swinkels \& Rzezniczak (2009) in three ways. First, we employ an extended survivorship controlled database of 140 funds (over the January 2000 - January 2008 period). Second, we measure performance using the 4-factor Carhart model designed to control for investment style. Third, we add persistence tests to measure the extent to which Polish mutual funds exhibit a predictable return behaviour.

The main added value of our study to the existing mutual fund literature is three-fold. First, it provides evidence on the performance of emerging market funds managed within an emerging market, in contrast to studies that analysed funds from the perspective of mature markets investing in emerging markets. This sheds light on the performance of local versus foreign fund managers. Second, the Polish fund market enables us to study the impact of a fast growing market on fund performance. Third, we study performance and persistence in performance in an emerging market using a survivorship bias controlled database using state of the art multi-factor asset pricing models.

The paper is organized as follows. The next section presents the development and characteristics of Polish mutual fund industry. Section 3 contains data description and summary statistics of the data. Section 4 provides a description of the model used to evaluate performance. The results of the analysis are described in section 5. Finally, section 6 presents conclusions. 


\section{Characteristics of the Polish mutual fund industry}

The history of Polish mutual fund industry started with the expansion of managing company Pioneer in the middle of $1992^{3}$. The family of Pioneer funds enjoyed monopoly until the beginning of 1995 . The period of 1996-2000 was characterised by the growth in a number of managing companies from 3 to 20 and an increase of funds to 81. In December 2000 the value of the assets under management exceeded PLN 7 billions. In the following years, despite the fluctuation on local and world stock markets, the Polish funds experienced healthy flow of funds in the range of PLN 4-10 billions per annum. The exponential growth of industry took place in the period between 2005 and mid of 2007 after EU accession when the growth of assets under management reached values up to $60 \%$ per year. It was a period when some of those funds achieved a return of almost $100 \%$ per year. The funds investing in small and mid cap stocks generated the highest returns to their participants; two leading funds were DWS Top 25 small companies, and ING mid-size and large companies.

The Polish mutual fund industry is characterised by a significant presence of foreign firms, which posses a combined market share of $74 \%$. This in contrast to for instance Germany (19\%), France (16\%) and the United Kingdom (44\%) ${ }^{4}$. This can partly be explained by the high foreign bank ownership in Central and Eastern European countries. According to Havrylychyk (2009) average foreign bank ownership in CEE amounted to $75 \%$ of total banking assets.

\footnotetext{
${ }^{3}$ The history of Polish stock market goes back to the beginning of the nineteenth century, when the first stock exchange was founded. Having been closed during both World Wars and the communist era, the Polish stock market was re-opened on 16 April 1991 with a listing of four companies. Three years later, the WIG20 stock price index was launched. This index reflects the performance of twenty blue chip stock listed on the main market of the Warsaw Stock Exchange (WSE). The Polish stock market has been growing rapidly in part because formerly state-owned companies were privatised and listed on the WSE. Since 1th May 2004, the market structure of the exchange has been in the process of complying with EU standards, i.e securities trading have two segments, the main market and the regulated unofficial parallel market.

${ }^{4}$ Source: Ferreira and Ramos (2009).
} 
By the end of 2007 the number of managing companies reached 33 and the size of assets under management exceeded PLN 134 billions. At the same time the capitalization of Polish stock market reached PLN 509 billions $^{5}$ and the number of companies listed on both segments was 351. The number of open-end funds offered to Polish investors reached 277. In years 2006 and 2007 the number of new funds entering the market was 60 and 111 respectively. The average size of the open-end fund across all investment classes was USD 134 million. For the sake of comparison, the average Western European fund has a size of USD 230 million, and US fund around USD 650 million (see Otten and Schweitzer (2002)).

The most popular among investors were balanced funds (with an estimated market share of 50.9\%) and equity funds (with almost one third of all assets). Far less popular were bond and money market funds. Their market shares were reduced for the third consecutive year and reached the level of $6.60 \%$ and $6.20 \%$ respectively. In recent years more money has flown to commodity and special funds having properties of hedge funds. Their share of market went above 7\% by the end of year 2007.

\section{Data}

Mutual fund data is extracted from three sources. Fund returns were obtained from the Polish Press Agency ${ }^{6}$, information on fee structures and net value of assets (NAV) was extracted from funds' annual reports and general information on the development of industry was sourced from the Polish Chamber of Fund and Asset Management (Izba Zarzadzajacych Funduszami i Aktywami).

Using the Polish Press Agency we identified all retail equity, bond and mixed mutual funds for the period from 01/2000 till 01/2008. Furthermore, we divided funds into

\footnotetext{
${ }^{5}$ The average exchange rate of USD in the year 2000 was equal to 4.35 PLN, in 2001 - 4.09 PLN, and in 2002 4.08 PLN.

${ }^{6}$ The data is downloadable from the website of brokerage house http://bossa.pl/ .
} 
investment categories based on their regional focus (domestic versus international) and strategy (equity, bond, mixed). We restrict our sample to retail funds with at least 12 months of data. The data on returns was collected from the Polish Press Agency. All returns are inclusive of any distributions, net of annual management fees and in local currency. This leads to a total sample of 140 open-ended mutual funds, of which 100 invest domestically and 40 invest internationally. As pointed out by Brown et al. (1992), leaving out dead funds leads to an overestimation of average performance. To limit a possible survivorship bias our sample also includes funds that were closed at any point during the sample period. Dead funds were included in the sample until they disappeared, after which the portfolios are reweighted accordingly. 26 out of 140 funds disappear before the end of our sample period. Table I provides a first overview of our database.

\section{[Insert Table I about here]}

Table I clearly indicates the dominance of domestic mixed funds in the Polish market. Together with domestic equity funds they account for over $80 \%$ of the total market based on assets under management. In contrast, internationally investing funds only represent a minor stake in the Polish market. This might be due to the home-bias effect, high front load and management fees of internationally investing funds. Also the appreciation of the local currency during examined period seems to discourage local investors.

Table I also highlights the rather extreme level of costs that are charged to investors in Polish funds. Khorana et al. (2009) report a worldwide average management fee of $0.9 \%$ and 2.5\% front end loads for domestic equity funds. In contrast, Polish domestic equity funds charge investors an average management fee of $3.67 \%$ and front end load of $4.46 \%$. The same holds for bond funds, with an average management fee of $2.13 \%$, compared to $0.68 \%$ 
based on worldwide evidence by Khorana et al. (2009). This leads us to believe that competition between funds in Poland is still limited.

Table II presents summary statistics on the 140 funds in our sample, sorted into 6 different categories based on regional focus (domestic, international) and strategy (equity, bond, mixed). Over the sample period domestic equity funds delivered the highest return, followed by domestic mixed funds. The average return of all international funds is negative.

[Insert Table II about here]

Based on Otten \& Bams (2002) we believe the size of a countries' mutual fund sector relative to the domestic market capitalisation has an influence on risk-adjusted performance. Figure 1 displays the size of the total equity, bond and mixed open-end mutual fund sector as a percentage of the respective market capitalisation. From Figure 1 it becomes clear that all three segments only present a minor stake in the domestic market capitalisation. On average, Polish equity mutual funds represent less than 5\% of domestic market capitalisation, which is far below European (about 10\%) and US statistics (about 30\%). In their study Otten \& Bams (2002) find that European mutual funds perform better compared to US mutual funds. The authors suggest that this is due to the smaller importance of the European mutual fund industry compared to the domestic market capitalisation. As the European fund industry as a whole only covers about $10 \%$ of the total market it might be more easy for them to outperform the remaining $90 \%$ of the market capitalisation, compared to the US where the entire fund industry is three times as big. This argument might also hold for the Polish market, where mutual funds represent even less than $5 \%$ of the market. This smaller market importance might put Polish fund managers in a better position to outperform their relevant benchmark. 
[Insert Figure 1 about here]

\section{Methodology}

The most basic model used in studies on equity mutual fund performance is a CAPM single index model. Recent literature on the cross-sectional variation of stock returns (see, e.g. Fama \& French $(1993,1996))$ however leads us to question the adequacy of a single index model to explain mutual fund performance. The Fama \& French (1993) 3-factor model is considered to give a better explanation of fund behaviour. In addition to a value-weighted market proxy, this model includes two additional risk factors, size (SMB) and book-to-market (HML). Although this model already improves average CAPM pricing errors, it is not able to explain the cross-sectional variation in momentum-sorted portfolio returns. Therefore Carhart (1997) extends the Fama-French model by adding a fourth factor that captures the Jegadeesh \& Titman (1993) momentum anomaly (PR1YR). The resulting model is consistent with a market equilibrium model with four risk factors, which can also be interpreted as a performance attribution model, where the coefficients and premia on the factor-mimicking portfolios indicate the proportion of the mean return attributable to four elementary strategies. By now, this has become the standard model to measure mutual fund performance. For an overview of all available mutual fund performance models please refer to, for instance, Otten \& Bams (2004). Formally, we estimate:

$$
R_{i t}-R f_{t}=\alpha_{i}+\beta_{0 i}\left(R m_{t}-R f_{t}\right)+\beta_{1 i} S M B_{t}+\beta_{2 i} H M L_{t}+\beta_{3 i} P R 12 m_{t}+\varepsilon_{t i}
$$

where

$\begin{array}{lll}\alpha_{i} & = & \text { Cahart's alpha measure for fund } i \\ \mathrm{R}_{i t} & = & \text { the return on fund } i \text { in month } t \\ \mathrm{Rf}_{t} & = & \text { the 1-month risk free in month } t\end{array}$




\begin{tabular}{|c|c|c|}
\hline $\mathrm{Rm}_{t}$ & $=$ & the return on the market benchmark in month $t$ \\
\hline $\mathrm{SMB}_{t}$ & $=$ & $\begin{array}{l}\text { the difference in return between a small cap portfolio and a } \\
\text { large cap portfolio at time } t\end{array}$ \\
\hline $\mathrm{HML}_{t}$ & $=$ & $\begin{array}{l}\text { the difference in return between a portfolio of high } \\
\text { book-to-market stocks and one of low book-to-market } \\
\text { stocks at month } t\end{array}$ \\
\hline $\mathrm{PR}_{12 \mathrm{~m}_{t}}$ & $=$ & $\begin{array}{l}\text { the difference in return between a portfolio of past } 1 \\
\text { year winners and a portfolio of past } 1 \text { year losers at } \\
\text { time } t\end{array}$ \\
\hline & $=$ & error term \\
\hline
\end{tabular}

Otten \& Bams (2004) test the validity of several mutual fund performance measurement models. The authors provide evidence for the additional usefulness of conditional models over unconditional multi-factor models. By conditioning the factors on a set up predetermined variables (term spread, dividends etc) the model allows for time-variation in beta's. Conditional models however put larger emphasis on statistical power of the employed tests. A 4-factor conditional model for instance adds $4 \times 4$ factors and leads, which leads to a significant loss in degrees of freedom. Due to the relative short life of the Polish industry we decided to use an unconditional 4-factor model instead.

Our main database to construct the factors used in the 4-factor model is Worldscope. The advantage of using the Worldscope database is that it tracks the entire universe of polish stocks, including the smaller companies In contrast, MSCI and/or the local WIG 20 index only cover the largest and most liquid stocks. This however does not enable us to form portfolios based on smaller companies, which is needed for, among others, the SMB portfolio. Using the entire Worldscope universe allows for a more granular approach. For the 
excess market return we take the return on all stocks in the Worldscope respective universe (Poland for domestic funds and global for international funds) minus the Polish risk free rate. As its proxy we have used Polish 1-month interbank middle rate sourced from Thompson DataStream $^{7}$. We then ranked all stocks based on their size and assigned the bottom $20 \%$ of total market capitalization to the small portfolio. The remaining part goes into the large portfolio. SMB is the return difference between small and large portfolio. ${ }^{8}$ For the $H M L$ factor all stocks are ranked on their book-to-market ratio. The top 30\% of market capitalization is assigned to the high book to market portfolio and the bottom $30 \%$ to the low book-to-market portfolio. HML is obtained by subtracting the low from the high book-tomarket return. The momentum factor portfolio $P R 12 m$ is formed by ranking all stocks on their prior 12-month return. The return difference between the top 30\% and bottom 30\% by market capitalization then provides us with the $P R 12 m$ factor returns. All returns are accounted for corporate actions, such as dividends, stock splits and mergers.

For bond funds we estimate a 1-factor model using either a domestic or international bond index, JP Morgan Poland all maturities and JP Morgan Global Government Bonds, respectively. For mixed funds we use a hybrid model, that is, we augment the Carhart 4factor model with a local bond index -JP Morgan Poland all maturities. Both bond indices are available in DataStream database.

\footnotetext{
${ }^{7}$ Polish interbank offered rates are WIBOR and WIBID. Both are the average interest rates on the interbank deposit market in Poland. The reference WIBOR rates are set for the following maturities: O/N, T/N, SW, 1 month, 3, 6, 9 and 12 months. WIBOR and WIBID rates are calculated as the arithmetic mean of the rates quoted by the participants, after rejecting two outliers (the highest and lowest quote).

${ }^{8}$ It can be argued that the Polish market has large number of relatively small stocks and small number of very large stock. To address this concern we alternatively constructed SMB along the $5^{\text {th }}$ percentile. Based on results not reported here we concluded this did not influence our findings. These results are available upon request.
} 


\section{Results}

\subsection{Risk-adjusted performance}

The top rows of Table III summarize the results of applying the standard 4-factor Carhart model to equity and mixed funds and the 1-factor bond model to bond funds. The first inspection of the results shows negative alphas for all six equally weighted portfolios of funds. Domestic equity funds deliver a significantly negative alpha of $-3.41 \%$ per year, after correcting for the lower market beta (0.77) and small cap exposure $(0.28)$. The adjusted $\mathrm{R}^{2}$ of 0.92 suggest that the Carhart model does a good job in explaining fund performance. International equity funds also provide a negative alpha of $-3.52 \%$ per year, though insignificantly different from zero. Interestingly international equity funds display a preference for larger stocks (SMB of -0.17), which is consistent with the literature suggesting that domestic investors have an informational advantage over foreign investors, especially in smaller stocks. Therefore, foreign investors usually overweigh larger companies where informational asymmetries are less promiment. As indicated before, domestic mixed funds dominate the Polish fund market. Their performance is slightly negative (-1.14\% per year), but insignificantly different from zero. With both a low equity beta and bond exposure they seem to serve as a defensive vehicle.

[Insert Table III about here]

It is international funds that seem to provide low alphas the most, however with relative low adjusted $\mathrm{R}^{2} \mathrm{~s}$. This might however be due to a potential home bias in the international portfolios. To formally test for this we augment the Carhart model for both equity and mixed fund by adding a domestic equity index. These results can be found in the lower rows of Table III. They confirm the common belief that domestic investors overweigh their home 
market in international portfolios. Both equity and mixed international funds have a significant exposure to domestic equity, leading to a significantly higher adjusted $\mathrm{R}^{2}$. However, risk-adjusted performance deteriorates even further as a result of this. Both types of international funds now significantly underperform by a large magnitude $(-4.85 \%$ to $-6.18 \%$ per year). Along the same lines as testing for a home bias we also test for an international bias in the domestic funds, as displayed in Table III. The reason for that is that Polish funds are only required to invest at least $66 \%$ of their assets in the stated region. This means that domestic funds are allowed to invest up to $34 \%$ in international equity ${ }^{9}$. Not surprisingly, Table III shows that domestic funds exhibit statistically significant sensitivity to the movement of the international equity index. ${ }^{10}$ As a result of including those returns as additional explanatory variable in the Carhart model we observed a slight increase in domestic fund alpha's. Nevertheless, they remain negative and insignificantly different from zero.

To sum up, using data from an emerging market, we corroborate previous evidence that mutual funds underperform relevant indices. Even in a presumably less efficient emerging market like Poland, fund managers are not able to add sufficient value to make up for the expenses they charge. These results are in line with previous evidence by Swinkels and Rzezniczak (2009) who study 38 domestic polish funds using a 1-factor model. They conclude that domestic funds deliver slightly positive 1-factor Jensen's alpha, however insignificantly different from zero. In addition to that, our study finds that both domestic and international funds invest outside of their designated region. That is, domestic funds also invest internationally and international funds in their home market. Controlling for that leads to the conclusion that international funds underperform their benchmarks significantly, while domestic funds deliver alpha's that are statistically not different from zero. This

\footnotetext{
${ }^{9}$ For detail of Polish fund classification see documentation by Chamber of Fund and Asset Management (Izba Zarzadzajacych Funduszami i Aktywami): http://www.izfa.pl/files_user/Klasyfikacja-zasady.pdf

${ }^{10}$ Note that the international equity index excludes Poland.
} 
finding is consistent with the literature suggesting that domestic investors have an informational advantage over foreign investors, especially in smaller stocks.

\subsection{Management fees}

We have so far considered mutual fund returns net of costs. This means management fees were already deducted from the fund's return. ${ }^{11}$ To judge the abilities of mutual fund managers to follow the market we now add back management fees to the monthly excess returns and re-run our analysis. That is, we run the augmented Carhart model (including domestic and international equity indices) for equity and mixed funds and the 1 -factor bond model for bond funds. The results of this are summarised in Table IV. The most important result from this is that 2 out of 3 domestic funds categories now deliver significantly positive alphas. International funds still deliver negative alphas, though not statistically significantly from zero anymore. These results indicate that Polish domestic mutual funds are successful in security selection but charge too high fees to deliver out-performance. International funds disappoint both before and after fees are deducted, which is a result one would expect based on previous mutual fund literature and informational disadvantages from investing abroad.

\section{[Insert Table IV about here]}

\subsection{Persistence}

The hypothesis that mutual funds with an above average return in one period will also have an above average return in the next period is called the hypothesis of persistence in performance. This topic has been well documented in the finance literature. Hendricks, Patel \& Zeckhauser (1993) and Brown \& Goetzmann (1995) find evidence of persistence in mutual

\footnotetext{
${ }^{11}$ Loads however are not considered.
} 
fund performance over short-term horizons where Grinblatt \& Titman (1992), Elton, Gruber, Das \& Blake (1996) and Allen \& Tan (1999) document mutual fund return predictability over longer horizons. Carhart (1997) however shows that the "hot hands" effect is mainly due to persistence in expense ratios and the pursuing of momentum strategies. Contrary evidence comes from Jensen (1968), who does not find predictive power for alpha estimates. The importance of persistence analysis is stressed by Sirri \& Tufano (1998) who document large money inflows into last year's top performers and extractions from last year's losers. Finally, Zheng (1999) finds that this newly invested money is able to predict future fund performance, in that portfolios of funds that receive more money subsequently perform significantly better than those that lose money.

To investigate whether persistence in mutual fund performance is also present in Poland, we rank all funds within a specific category, based on past 12-month return. The 1/3 of funds with the highest previous period return (selection period) go into portfolio I (high) and the 1/3 funds with the lowest past period return go into portfolio III (low). The remaining 1/3 of funds go into portfolio II. These 3 equally weighted portfolios are then held for 12 months, before we rebalance them again based on their last return. This is continued throughout the sample period until we get a time series of monthly returns on all 3 portfolios. Funds that disappear during the year are included until they disappear, after which portfolio weights are re-adjusted accordingly. Note that we only perform this analysis for domestic equity and domestic mixed funds where we have enough funds to sort into 3 portfolios.

[Insert Table V about here]

Table $\mathrm{V}$ reports the results of the above described procedure for domestic equity and domestic mixed funds. Other classes of funds were excluded from the analysis as they 
contain 15 or less funds each. For both examined classes we observe a monotonically decreasing excess return if we move from high- to low-past performance portfolio. The monthly average spread between the high- and low-portfolios is $1.46 \%$ and $1.12 \%$ for domestic equity and domestic mixed funds respectively. Interestingly, for all examined classes we observed a statistically significant spread. In addition, there is not much difference between volatilities of returns across portfolios in a given group. Thus, on Polish markets the best and worst performing funds expose an investor to a comparable risk measured in terms of standard deviation of returns. Our preliminary analysis has shown that Polish mutual funds' performance is persistent. In search of further verification, we used 4-factor Carhart model. The application of this method gives us a chance to examine persistence of riskadjusted performance. Controlling for market excess return, book-to-market ratio, size, and momentum strategy does not alter our conclusions. Both domestic equity and mixed funds' spreads are positive and statistically significant. The spread is $1.33 \%$ and $1.18 \%$ for equity and mixed funds respectively.

In contrast to the previous studies on the US and Europe see Hendricks et al. (1993), Brown \& Goetzmann (1995), Carhart (1997) and Otten \& Bams (2002), Polish domestically oriented funds exhibit strong persistence. Excluding transaction cost, the strategy buying last year's top funds and selling last year's bottom funds yields a return in the range of $13.44 \%$ and $17.52 \%$ per year. Such strategy remains attractive even after including the relatively high front lead fees that are charged by Polish funds (on average $4.46 \%$ and $2.88 \%$ for domestic equity and mixed fund respectively). The observed difference in performance of best and worst funds cannot be explained by the risk factors proposed by Cahart (1997). The most striking result is that the top funds (high) produce a significantly positive alpha, and therefore, persistence is not just driven by "icy hands" but true "hot hands". This in sharp contrast to previous literature on developed markets, as cited before. 
[Insert Table V about here]

\subsection{The influence of fund characteristics on risk-adjusted performance.}

In this section we examine if the performance of Polish funds can be attributed to their basic characteristics such as the size measured by net value of assets under management, and age in years. Moreover, we verify if investors allocating money in funds with higher expenses are rewarded with better risk-adjusted performance. In order to analyse the impact of fund's characteristics on their performance, we consider the following regression:

$$
\alpha_{i}=c_{0}+c_{1} \text { Expense_ratio }_{i}+c_{2} \operatorname{Ln}(\text { Assets })_{i}+c_{3} \operatorname{Ln}(\text { Age })_{i}+\varepsilon_{i}
$$

where

$\alpha_{i} \quad$ : Cahart's alpha for fund $i$,

Expense_ratio $_{i}$ : Expense ratio for fund $i$,

Ln(Assets) $)_{i I} \quad$ : natural logarithm of total fund assets for fund $i$,

$\operatorname{Ln}(\text { Age })_{i} \quad$ : natural logarithm of age in years for fund $i$,

$\varepsilon_{i} \quad:$ the error term

[Insert Table VI about here]

In Table VI the results of the above regression are reported. The size of assets under management is the only variable which has statistically significant positive impact on fund performance. Our results indicated the presence of negative correlation between risk-adjusted 
performance and following variables: expense ratio and the age of funds. However, none of them is statistically significant.

The negative relationship between expense ratio and risk-adjusted performance were previously reported for US industry by Elton et al. (1993), Malkiel (1995) and Carhart (1997). Inverse relationship was reported for mature European countries (Dahlquist et al. (2000) and Otten \& Bams (2002)). In contrast to the US industry and similarly to the European one, the risk-adjusted performance of Polish mutual funds is positively correlated with natural logarithm of fund assets. We believe that it can be explained by economies of scale. Not only the ratio of assets under management to market capitalization for Polish openend equity funds does not exceed 9\%, but also the average size of the fund across all investment classes is $\$ 134$ millions dollars. For the sake of comparison, the average Western European fund is twice and the US fund is more than five time bigger. Therefore, it seems that Polish funds can still grow and they are far from reaching the point of underperforming due to the size.

\section{Conclusions}

This study investigates the Polish mutual fund industry. More specifically we test the performance and persistence in performance of a survivorship controlled sample of 140 mutual funds over the 2000-2008 period using a multi-factor Carhart model. The Polish mutual fund industry provides an excellent opportunity to test performance in an emerging market. On the one hand weaker legal institutions and an underdeveloped capital market might influence mutual fund performance negatively. On the other hand the small size of the industry compared to the total market capitalisation and the presumably less efficient market creates opportunities for managers to beat the market. 
Our main conclusions are five-fold. First, we corroborate the evidence found in previous studies on developed markets; Polish funds underperform their relevant benchmarks. Second, domestic funds outperform international funds. While domestic funds produce Carhart alpha's that are indifferent from zero, international funds underperform significantly. Third, both domestic and international funds have exposure outside their region. That is, international funds exhibit a home bias and domestic funds also invest internationally. This confirms earlier results where domestic investors profit from informational advantages over foreign investors. Fourth, adding back management fees to excess returns leads to significantly positive alpha's for domestic funds, while international funds now produce alphas that are indifferent from zero. This reveals the fact that domestic managers are able to beat their local market, but charge investors too much for this. Fifth, we document strong persistence in performance. The strategy of buying last year's top funds and selling last year's bottom funds yields a return in the range of $13.44 \%$ to $17.52 \%$ per year. In contrast to previous studies, this effect is both driven by icy hands and hot hands. More specifically, the strategy of buying winners produces significantly positive alpha's while the losers produce significantly negative alpha’s.

\section{Acknowledgements}

We are grateful to an anonymous referee and participants of the seminar at Department of Economics and Finance University of Canterbury, for valuable comments. Part of this research was conducted while Bialkowski was affiliated with Auckland University of Technology (AUT) and Otten was a visiting scholar at AUT. Finally, we would like to thank Judith van Buggenum for research assistance. Jędrzej Białkowski is grateful to BNZ bank for funding support, but none of the views expressed in this paper should be attributed to them. The views expressed in this paper are not necessarily shared by Philips Pension fund. 


\section{References}

Allen, D. E. \& Tan, M. L. (1999). A Test of the Persistence in the Performance of UK Managed Funds, Journal of Business Finance \& Accounting, 26, 559-593.

Blake, D. \& Timmermann. A. (1998). Mutual fund performance: evidence for UK, European Finance Review, 2, 57-77.

Borensztein, E.R. \& Gelos, R.G., (2000). A Panic-Prone Pack? The Behavior of Emerging Market Mutual Funds, IMF Working paper, WP/00/198.

Brennan, M.J. \& Cao, H.H. (1997). International portfolio investment flows. Journal of Finance, 52, 1851-1880.

Brown, S.J., \& Goetzmann, W.N. (1995). Performance persistence, Journal of Finance, 50, 679-698.

Brown, S. \& Goetzmann W., Ibbotson R. \& Ross S. (1992). Survivorship bias in performance studies, Review of Financial Studies, 5, 553-580.

Carhart, M. (1997). On Persistence in Mutual Fund Performance, Journal of Finance, 52, 5782.

Coval, J. D. \& Moskowitz, T. J. (1999). Home bias at home: Local equity preference in domestic portfolios, Journal of Finance, 54, 2045-2074.

Dahlquist, M., Engstrom, S. \& Soderlind, P. (2000). Performance and characteristics of Swedish mutual funds, Journal of Financial and Quantitative Analysis, 35, 409-423.

Dermine, D. \& Roller. L.H. (1992). Economies of scale and scope in French mutual funds, Journal of Financial Intermediation, 2, 83-93.

Elton, E. M., Gruber, Das S. \& Blake C. (1996). The persistence of risk-adjusted mutual fund Performance, Journal of Business, 69, 133-157.

Elton, E.J., Gruber, M.J., Das, S., \& Hlavka, M. (1993). Efficiency with costly information: A reinterpretation of evidence from managed portfolios, Review of Financial Studies, 6, 1-22.

Fama, E. \& French K.R. (1996). Multifactor Explanations of Asset Pricing Anomalies, Journal of Finance, 51, 55-84.

Fama, E., \& French K., (1993). Common risk factors in the returns on stocks and bonds, Journal of Financial Economics, 33, 3-56.

French. K.R. (2008). The Cost of Active Investing, Social Science Research Network, Working paper.

Ferreira, M.A., Miguel, A.F., \& Ramos, S. (2006). The determinants of mutual fund performance: A cross-country study, Swiss Finance Institute Research Paper, 30. 
Ferreira, Miguel A. and Ramos, Sofia Brito, Mutual Fund Industry Competition and Concentration: International Evidence, Social Science Research Network, Working paper.

Fernandez P., Bermejo V. J. \& Bilan, A. (2008). Poor performance of mutual funds in Spain. 1991-2007, IESE Research Papers, No D/746

Grinblatt, M. \& Titman S. (1992). The persistence of mutual fund performance, Journal of Finance, 47, 1977-1984.

Gruber M.J. (1996). Another Puzzle: The Growth in Actively Managed Mutual Funds, Journal of Finance, 51, 783-810.

Havrylchyk, O. (2009). Will Western European Banks Pull Out of Central and Eastern Europe?, La Lettre du CEPII N²88.

Hendricks, D., J. Patel, \& R. Zeckhauser, (1993). Hot hands in mutual funds: Short-run persistence of relative performance 1974-1988, Journal of Finance, 48, 93-130.

Huij, J. \& Post. R.G. (2009), On the Performance of Emerging Market Equity Mutual Funds, Social Science Research Network, Working paper.

Hau H. (2001). Location matters. Journal of Finance, 56, 1959-1983.

Jegadeesh, N., \& Titman, S., (1993). Returns to Buying Winners and Selling Losers: Implications for Stock Market Efficiency, Journal of Finance, 48, 65-91.

Jensen, M. (1968). The performance of mutual funds in the period 1945-1964, The Journal of Finance, 23, 389-416.

Jensen, M. (1969). Risk, the pricing of capital assets and evaluation of investment portfolios, Journal of Business, 42, 167-247.

Khorana A., Servaes H. \& Tufano P. (2009). Mutual Fund Fees Around the World, Review of Financial Studies, 22, 1279-1310.

Khorana A., Servaes H. \& Tufano P. (2005). Explaining the size of the mutual fund industry around the world, Journal of Financial Economics, 78, 145-185.

Malkiel B.G. (1995). Returns from Investing in Equity Mutual Funds 1971 to 1991, Journal of Finance, 50, 549-572.

Otten R., \& Bams D. (2002). European Mutual Fund Performance, European Financial Management, 8, 75-101.

Otten, R., \& Schweitzer M. (2002) A comparison between the European and the U.S. mutual fund industry, Managerial Finance, 28, 14-35.

Otten R, \& Bams D. (2004) How to measure mutual fund performance, Accounting \& Finance, 44, 203-222 
Otten R, \& Bams D. (2007). The performance of local versus foreign mutual fund managers, European Financial Management, 13(4), 702-720

Shukla, R. \& van Imwegen, G. (1995). Do locals perform better than foreigners? An analysis of UK and US mutual fund managers, Journal of Economics and Business, 47.

Rompotis, G.G. (2007). Can Greek Mutual Fund Managers Outguess the Market Persistently, Social Science Research Network Working paper.

Sirri, E.R. \& P. Tufano P. (1998). Costly Search and Mutual Fund Flows, Journal of Finance, 53, $1589-1622$.

Sorros, J.N. (2001). Equity mutual fund managers' performance in Greece, Managerial Finance, 27, 68-75.

Swinkels, L., \& Rzezniczak P. (2009). Performance evaluation of Polish mutual fund managers, International Journal of Emerging Markets, 4, 26-42.

Stanko, D. (2003). Performance Evaluation of Public Pension Funds: The Reformed Pension System in Poland, Discussion Paper PI-0308 (The Pensions Institute, Birkbeck College, University of London).

Ter Horst, J., Nijman, Th. \& De Roon, F. (1998). Style analysis and performance evaluation of Dutch mutual funds, CentER discussion paper 9850.

Voronkova S., \& Bohl M. (2005). Institutional Traders' Behavior in an Emerging Stock Market: Empirical Evidence on Polish Pension Fund Investors, Journal of Business Finance \& Accounting, 32, 1537-1560.

Ward, C. \& Saunders A. (1976). UK unit trust performance 1964 to 1974, Journal of Business Finance \& Accounting , 3/4, 83-97.

Wittrock, C. \& Steiner, M., (1995). Performance-messung ohne Rueckgriff auf Kapitalmarkttheoretische renditeerwatungsmodelle, Kredit unf Kapital, 1-45.

Zheng L. (1999). Is Money Smart? - A Study of Mutual Fund Investors' Fund Selection Ability, Journal of Finance, 54, 901-933. 
Table I. Summary statistics Polish mutual funds, 2000-2007.

\begin{tabular}{|c|c|c|c|c|c|c|}
\hline Type of fund & $\begin{array}{l}\text { Net Asset Value } \\
\text { (in billions PLN) }\end{array}$ & $\begin{array}{r}\text { Number of } \\
\text { funds }\end{array}$ & $\begin{array}{r}\text { Average size } \\
\text { (in millions } \\
\text { PLN) }\end{array}$ & $\begin{array}{r}\text { Average } \\
\text { management } \\
\text { fee }(\%) \\
\end{array}$ & $\begin{array}{r}\text { Average } \\
\text { front load } \\
(\%) \\
\end{array}$ & $\begin{array}{l}\text { Average age } \\
\text { (in years) }\end{array}$ \\
\hline Domestic Equity & 20.00 & 30 & 833.62 & 3.67 & 4.46 & 7.13 \\
\hline Domestic Bonds & 7.13 & 29 & 274.13 & 2.13 & 0.98 & 6.88 \\
\hline Domestic Mixed & 43.44 & 41 & 1143.26 & 3.15 & 2.88 & 6.18 \\
\hline International Equity & 2.40 & 13 & 3.58 & 4.88 & 3.58 & 5.39 \\
\hline International Bonds & 1.77 & 15 & 2.02 & 1.23 & 2.05 & 4.55 \\
\hline International Mixed & 1.96 & 12 & 2.86 & 3.75 & 2.86 & 3.37 \\
\hline Overall & 76.80 & 140 & 376.58 & 3.14 & 2.80 & 5.58 \\
\hline
\end{tabular}

The table reports summary statistics of the 140 funds in our sample. The Net Asset Value and Average size is given in Polish zloty (PLN). 
Table II. Summary statistics for excess monthly returns

\begin{tabular}{c|ccccc}
\hline Type of fund & Mean & Stddev & Skewnes & Q25 & Q75 \\
\hline Domestic Equity & 0.00248 & 0.01263 & -0.80854 & -0.00449 & 0.01125 \\
Domestic Bond & -0.00055 & 0.00116 & 0.16896 & -0.00112 & -0.00001 \\
Domestic Mixed & 0.00336 & 0.00611 & 2.35401 & 0.00062 & 0.00545 \\
International Equity & -0.00243 & 0.00901 & 0.36039 & -0.00859 & 0.00420 \\
$\begin{array}{c}\text { International } \\
\text { bond }\end{array}$ & -0.00788 & 0.00341 & 0.86894 & -0.00956 & -0.00611 \\
$\begin{array}{c}\text { International Mixed } \\
\text { Nat }\end{array}$ & -0.00741 & 0.01772 & -2.63498 & -0.01124 & 0.00242 \\
\hline
\end{tabular}

The table reports the arithmetic average, standard deviation (Stddev), skewness and two percentiles for monthly excess return. 
Table III. Polish Mutual Fund performance

\section{Panel A: Standard Carhart and 1-factor bond model}

\begin{tabular}{cccccccc}
\hline Type of fund & $\alpha$-alpha & RMRF & SMB & HML & PR12m & Bond & ADJ. $\mathrm{R}^{2}$ \\
\hline Domestic Equity & $-3.41^{*}$ & $0.77^{* * *}$ & $0.28^{* * *}$ & -0.00 & -0.02 & & 0.92 \\
Domestic Bond & $-1.49^{* *}$ & & & & & $0.42^{* *}$ & 0.81 \\
Domestic Mixed & -1.14 & $0.34^{* *}$ & $0.09^{* *}$ & -0.02 & -0.01 & $0.13^{* *}$ & 0.92 \\
\hline International Equity & -3.52 & $0.62^{* * *}$ & $-0.17^{*}$ & -0.07 & -0.01 & & 0.68 \\
International Bond & -2.61 & & & & & $0.53^{* *}$ & 0.52 \\
International Mixed & $-5.69^{*}$ & $0.43^{* *}$ & $0.25^{*}$ & $-0.29^{* * *}$ & -0.07 & $-0.38^{* *}$ & 0.54 \\
\hline
\end{tabular}

Panel B: Home and International bias test

\begin{tabular}{|c|c|c|c|c|c|c|c|c|c|}
\hline Type of fund & $\alpha$-alpha & RMRF & SMB & HML & PR12m & Bond & $\begin{array}{c}\text { Domestic } \\
\text { Equity }\end{array}$ & $\begin{array}{l}\text { Interna } \\
\text {-tional } \\
\text { Equity }\end{array}$ & $\begin{array}{l}\text { ADJ. } \\
\mathrm{R}^{2}\end{array}$ \\
\hline Domestic Equity & -1.37 & $0.72^{* * *}$ & $0.25^{* * *}$ & -0.02 & -0.02 & & & $0.17^{* *}$ & 0.93 \\
\hline Domestic Mixed & -0.82 & $0.31^{* *}$ & $0.08^{* *}$ & -0.02 & -0.00 & $0.13^{* *}$ & & $0.05^{*}$ & 0.94 \\
\hline $\begin{array}{c}\text { International } \\
\text { Equity }\end{array}$ & $-4.85^{* *}$ & $0.55^{* * *}$ & $-0.25^{* *}$ & -0.03 & -0.02 & & $0.13^{* *}$ & & 0.74 \\
\hline $\begin{array}{l}\text { International } \\
\text { Mixed }\end{array}$ & $-6.18^{* *}$ & $0.24^{* *}$ & $0.11^{*}$ & $-0.25^{* *}$ & $-0.12^{* *}$ & $-0.07^{*}$ & $0.27^{* *}$ & & 0.81 \\
\hline $\begin{array}{l}R M R F \text { is the dif } \\
\text { difference in retl } \\
\text { between a portfol } \\
\text { in return between } \\
\text { statistical signific }\end{array}$ & $\begin{array}{l}\text { nce bet } \\
\text { betweer } \\
\text { f high b }\end{array}$ & el of 10 & rn on & nners & $\begin{array}{l}\text { w boo } \\
\text { portf }\end{array}$ & and $\mathrm{t}$ & $\begin{array}{l}\text { stocks. } \\
1 \text { year lo }\end{array}$ & $\begin{array}{l}\mathrm{k} \text { free. } \\
\text { fference } \\
2 m \text { the } \\
\text { s.***, }^{*} \text {, }\end{array}$ & $\begin{array}{l}\text { MB the } \\
\mathrm{n} \text { return } \\
\text { fference } \\
* \text { denote }\end{array}$ \\
\hline
\end{tabular}


Table IV Polish Mutual Fund performance before and after fees

\begin{tabular}{cll}
\hline Type of fund & $\begin{array}{l}\text { After fees } \\
\text { Net alpha }\end{array}$ & $\begin{array}{l}\text { Before fees } \\
\text { Gross alpha }\end{array}$ \\
\hline Domestic Equity & -1.37 & $2.30^{*}$ \\
Domestic Bond & $-1.49^{* *}$ & -0.64 \\
Domestic Mixed & -0.82 & $2.33^{* *}$ \\
\hline International Equity & $-4.85^{* *}$ & 0.03 \\
International Bond & -2.61 & -1.38 \\
International Mixed & $-6.18^{* *}$ & -2.43 \\
\hline
\end{tabular}

The table gives alphas after costs are deducted (column 2) and before (column 3) costs are deducted from fund returns. All alphas are annualized. ***, **,* denote statistical significance at the level of $1 \%, 5 \%$ and $10 \%$. 
Table V. Persistence in Polish mutual funds performance

\begin{tabular}{ccccc|cccc} 
& \multicolumn{4}{c}{ Domestic Equity } & & \multicolumn{3}{c}{ Domestic Mixed } \\
\cline { 2 - 9 } Portfolio & I -(high) & II & III-(low) & $\begin{array}{c}\text { Spread } \\
\text { (high -low) }\end{array}$ & I -(high) & II & III-(low) & $\begin{array}{c}\text { Spread } \\
\text { (high -low) }\end{array}$ \\
\hline Mean & 0.0098 & 0.0024 & -0.0048 & $0.0146^{* * *}$ & 0.0067 & 0.0008 & -0.0045 & $0.0112^{* * *}$ \\
STD & 0.0547 & 0.0524 & 0.0495 & 0.0052 & 0.0261 & 0.0238 & 0.0257 & 0.0004 \\
Q5 & -0.0905 & -0.0938 & -0.0943 & 0.0038 & -0.0384 & -0.0367 & -0.0547 & 0.0163 \\
Q95 & 0.1056 & 0.0844 & 0.0713 & 0.0343 & 0.0473 & 0.0335 & 0.0319 & 0.0154 \\
\hline$\alpha-$ Alpha & $0.0041^{* * *}$ & $-0.0031^{* *}$ & $-0.0092^{* * *}$ & $0.0133^{* * *}$ & $0.0046^{* * *}$ & $-0.0028^{* *}$ & $-0.0072^{* * *}$ & $0.0118^{* * *}$ \\
RMRF & $0.8293^{* * *}$ & $0.7976^{* * *}$ & $0.6807^{* * *}$ & $0.1486^{* * *}$ & $0.3694^{* * *}$ & $0.3532^{* * *}$ & $0.3101^{* * *}$ & $0.0593^{* *}$ \\
SMB & $0.2939^{* * *}$ & $0.2088^{* * *}$ & $0.3111^{* * *}$ & -0.0172 & $0.0751^{* *}$ & $0.1037^{* * *}$ & $0.0747^{* *}$ & 0.0004 \\
HML & 0.0115 & $0.0530^{* *}$ & -0.0563 & $0.0678^{* *}$ & 0.0015 & 0.0181 & $-0.0767^{* * *}$ & $-0.0752^{* * *}$ \\
PR12m & -0.0043 & 0.0301 & -0.5849 & 0.5806 & $0.0456^{*}$ & -0.0200 & $-0.0636^{* *}$ & $0.0180^{* * *}$ \\
BND & N/A & N/A & N/A & N/A & -0.0373 & $0.1518^{* * *}$ & $0.1954^{* *}$ & $0.2327^{* *}$ \\
ADJ. R2 & 0.9375 & 0.9312 & 0.8090 & 0.1285 & 0.8695 & 0.9075 & 0.7778 & 0.1020 \\
\hline
\end{tabular}

The table reports result for domestic mixed and equity funds. For both classes of funds we construct three equally weighted portfolios based on the performance during the last 12-months. Funds with the highest previous 12-month return are allocated into portfolio I and funds with the lowest go into portfolio III. The first panel presents the basic statistics of excess returns for each of the portfolio. The column 5th and 9th columns report the spread between statistics for portfolio I (high performance) and III (weak performance).The second panel provides us with the analysis of portfolio performance control for such risk factor as market excess return, book-to-market ratio, size, and momentum strategy. RMRF is the difference between the return on the market benchmark and the 1-month risk free. SMB the difference in return between a small cap portfolio and a large cap portfolio. HML the difference in return between a portfolio of high book-to-market stocks and one of low book-to-market stocks. $P R 12 m$ the difference in return between a stock portfolio of past 1 year winners and a portfolio of past 1 year losers.***, $* * *$ denote statistical significance at the level of $1 \%, 5 \%$ and $10 \%$. 
Table VI The influence of fund characteristics on risk-adjusted performance

\begin{tabular}{cc}
\hline Variable & Coefficient \\
\hline Constant & -0.00520 \\
& $(-1.41)$ \\
Expense Ratio & -0.01199 \\
& $(-1.09)$ \\
$\operatorname{Ln}($ Assets $)$ & $0.00368^{* *}$ \\
& $(2.38)$ \\
$\operatorname{Ln}($ Age $)$ & -0.00334 \\
& $(-0.70)$ \\
\hline
\end{tabular}

The table shows the results of regression analysis given by equation $\alpha_{i}=c_{0}+c_{1}$ Expense $_{\text {ratio }}+c_{2} \operatorname{Ln}(\text { Assets })_{i}+c_{3} \operatorname{Ln}(\text { Age })_{i}+\varepsilon_{i}$ where $\quad \alpha_{i} \quad$ is Cahart's alpha for given fund, Expense_ratio $i$ is expense ratio for that fund, Ln(Assets) $\operatorname{Ln}(\text { Age })_{i}$ are natural logarithm of total fund assets and natural logarithm of age in years for that fund respectively. $* * *, * * * *$ denote statistical significance at the level of $1 \%, 5 \%$ and $10 \%$. 
Figure 1: Polish open-end mutual fund assets as a percentage of total market capitalisation

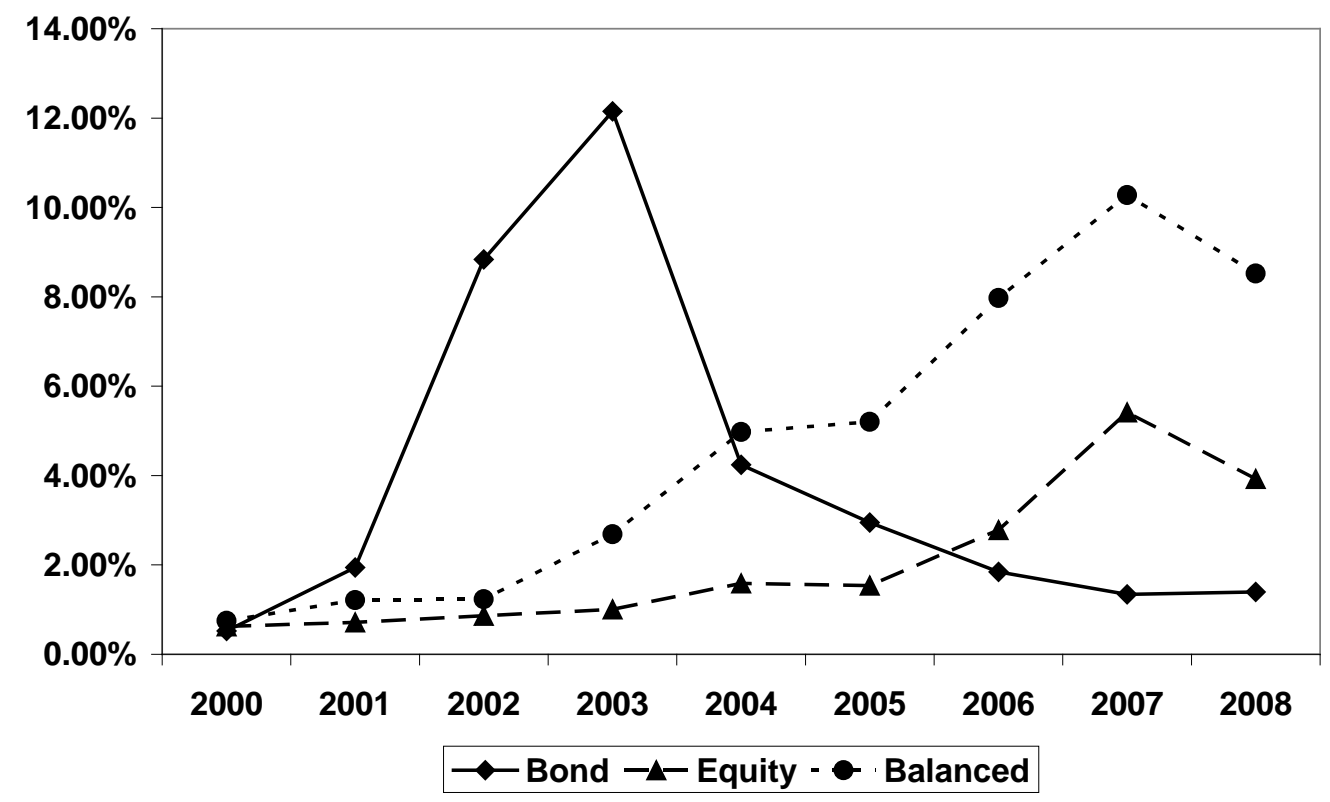

